University of New Hampshire

University of New Hampshire Scholars' Repository

Faculty Publications

$5-26-2016$

\title{
Uplift of Central Mongolia Recorded in Vesicular Basalts
}

D. Sahagian

Lehigh University

Alexander A. Prusevich

University of New Hampshire, Durham, alex.proussevitch@unh.edu

L. D. Ancuta

Lehigh University

B. D. Idleman

Lehigh University

P. K. Zeitler

Lehigh University

Follow this and additional works at: https://scholars.unh.edu/faculty_pubs

\section{Comments}

This is an article published by University of Chicago Press in The Journal of Geology in 2016, available online:

https://dx.doi.org/10.1086/686272

\section{Recommended Citation}

Sahagian, D., Proussevitch, A., Ancuta, L. D., Idleman, B. D., \& Zeitler, P. K. (2016). Uplift of Central Mongolia Recorded in Vesicular Basalts. The Journal of Geology, 124(4), 435-445. doi:10.1086/686272

This Article is brought to you for free and open access by University of New Hampshire Scholars' Repository. It has been accepted for inclusion in Faculty Publications by an authorized administrator of University of New Hampshire Scholars' Repository. For more information, please contact Scholarly.Communication@unh.edu. 


\title{
Uplift of Central Mongolia Recorded in Vesicular Basalts
}

\author{
D. Sahagian, ${ }^{1, \star}$ A. Proussevitch, ${ }^{2}$ L. D. Ancuta, ${ }^{1}$ B. D. Idleman, ${ }^{1}$ and P. K. Zeitler ${ }^{1}$ \\ 1. Earth and Environmental Sciences Department, Lehigh University, Bethlehem, Pennsylvania 18015, USA; \\ 2. Earth Systems Research Center, University of Hew Hampshire, Durham, New Hampshire 03824, USA
}

\begin{abstract}
A B S T R A C T
Epeirogenic histories of highland areas have confounded earth scientists for decades, as there are few sedimentary records of paleoelevation in eroding highlands. For example, mechanisms that have led to the high elevations of the Hangay Mountains in central Mongolia are not clear, nor is it well understood how the epeirogenic history of central Mongolia is connected to that of a broader region of high elevation that extends hundreds of kilometers to the north, east, and west. However, preserved basaltic lava flows record paleoelevation in the size distributions of vesicles at the tops and bottoms of flow units. As an initial step toward better understanding the tectonics of this part of Asia, we collected and analyzed samples from several basaltic lava flows from throughout the Hangay Mountains to use as a paleoaltimeter on the basis of lava flow vesicularity. Samples were dated and scanned with x-ray tomography to provide quantitative information regarding their internal vesicle size distributions. This yielded the pressure difference between the top and bottom of each flow for paleoelevation calculation. Results suggest that the Hangay Mountains experienced uplift of more than $1 \mathrm{~km}$ sometime during the past $9 \mathrm{~m}$.yr. The magnitude of uplift of the Hangay, in addition to the composition of its lavas, the geomorphology of the region, its drainage pattern history, and other proxies, bears on possible mechanisms for uplift of this part of central Asia.
\end{abstract}

Online enhancements: appendix.

\section{Introduction}

Regions of high elevation within continental interiors have emerged within the various continents, yet the driving mechanisms for uplift remain unclear in many cases. With the absence of convergent tectonics, traditional Wilson Cycle models of plate tectonics fail to explain why these continental interiors were uplifted. Numerous explanations have been proposed for the origin of uplifted continental interiors, such as dynamic topography supported by deep-mantle plumes /Geist and Richards 1993; Burov and Gerya 2014), asthenospheric upwelling driven by various mechanisms /de Ignacio et al. 2001), basaltic underplating (Powell 1986; Wendlandt et al. 1993), thickened crustal wedges (Lu et al. 2016), and various forms of lithospheric drips involving foundering or delamination of mantle or crustal lithosphere /Calixto et al. 2013; Bao

Manuscript received June 29, 2015; accepted February 10, 2016; electronically published May 26, 2016.

* Author for correspondence; e-mail: dork.sahagian@lehigh .edu. et al. 2014). One approach to constraining possible mechanisms or revealing additional ones is to determine the history of vertical motions (epeirogeny) of the plateau in question. However, epeirogenic histories of highland areas have confounded geophysicists for decades, as there are few quantitative records of paleoelevation in eroding highlands (Sahagian 2005). A novel technique has been developed for determining paleoelevation on the basis of the vesicularity profiles of basaltic lava flows /Sahagian and Maus 1994; Sahagian et al. 2002a; Sahagian and Proussevitch 2007). In this article, in order to provide an important constraint on potential mechanisms, we use this technique to determine the timing of uplift of the Hangay Mountains.

Preserved basalts record paleoelevation in the size distributions of vesicles at the tops and bottoms of flow units. Although the bubbles have identical mass distributions at the top and the base (being well mixed upon eruption from the vent), they are subject to different total pressures (thus, sizes) because of differences in overburden. At the

[The Journal of Geology, 2016, volume 124, p. 435-445] (c) 2016 by The University of Chicago. All rights reserved. 0022-1376/2016/12404-0001\$15.00. DOI: 10.1086/686272 
top of the flow the pressure is merely atmospheric pressure, but at the base of the flow there is the additional pressure of the weight of the overlying lava. Thus, the atmospheric-pressure dependence of vesicle size can be expressed by the ratio of vesicle size modes at the top and bottom of a flow. This is done by x-ray tomographic analysis of preserved preeruptive (and rarely syneruptive) vesicles from flow tops and bottoms. The atmosphere's paleopressure can thus be determined, and paleoelevation can then be calculated from the standard atmosphere (fig. 1). Once we know the ages and present elevations of a number of basalt flows, calculating paleoelevation in this way enables us to determine the amount of uplift or subsidence for each, thus providing a history of tectonic uplift or subsidence of the area. The total error bounds of the method for an individual sample are estimated to be $\pm 400 \mathrm{~m}$ (Sahagian et al. 2002a), which is sufficient only for major epeirogenic trends, such as that seen previously on the Colorado Plateau (Sahagian et al. 2002b; Sahagian and Proussevitch 2007) and now in Mongolia.

The Hangay Mountains in central Mongolia reach elevations of up to $4000 \mathrm{~m}$ and are characterized by generally low-relief landscape. The Hangay Mountains are situated within the Mongolian highland region and may share a tectonic and epeirogenic history with a broader region of high elevation that extends from the Valley of Lakes, to the southwest, north to the Hovsgol and Baikal rift zones. The mountains are bounded by several major strike-slip faults that isolate the Hangay as a relatively coherent crustal block within this broader region. Cenozoic volcanism occurred throughout the Hangay region; there is also evidence of relatively recent faulting, but the causal mechanisms of this activity are not well understood.

The high elevation and low relief of the Hangay Mountains are enigmatic, as there is no clear mechanism evident in the broader Asian tectonic environment to act on this particular region. There are a number of potential mechanisms that could, individually or in combination, have caused the uplift of the Hangay Mountains. Some potential mechanisms include lithospheric delamination, underplating, a mantle plume, mantle flow induced by the presence of the adjacent Siberian cratonic root, and far-field effects of either Pacific Plate subduction or

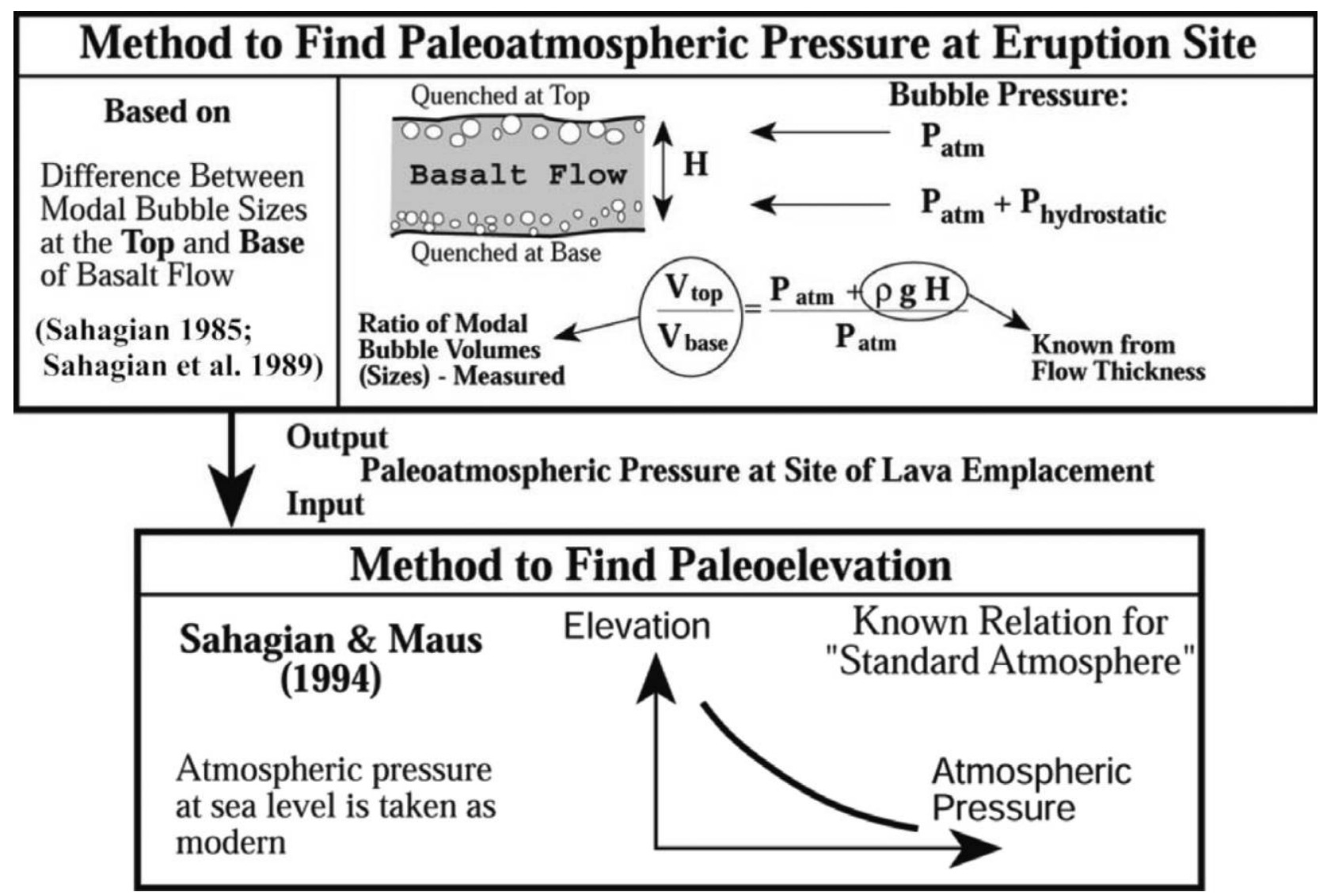

Figure 1. Diagrammatic representation of methodology for determining paleoelevation from vesicular basalt flows. 
Himalayan collisional tectonics. Alternatively, the uplift may be associated with the same broad-scale lithospheric stress field that has led to the development of the Baikal and Hovsgol rift systems (Parfeevets and Sankov 2012). Recent stable-isotope evidence suggests that uplift of the Hangay Mountains may have begun in the Oligocene, on the basis of reconstructed precipitation trends (Caves et al. 2014). Our study builds on previous work by providing some of the first results in quantifying the uplift of the Hangay Mountains. By providing additional constraints on its timing and extent, we take the next step in explaining the uplift of the Hangay Mountains.

\section{Basalts of the Hangay}

Cenozoic intraplate basaltic volcanism is common and widespread throughout much of central and east Asia. Geochemical studies of Cenozoic central and east Asian volcanic rocks have found that the majority of the rocks have a similar isotopic fingerprint that trends between enriched-mantle- and prevalent-mantle (PREMA)-type sources (Zindler and Hart 1986; Yarmolyuk et al. 2011). For the Hangay region, the source of the isotopic signature, and by inference the source of the basalts, remains contentious; it has been attributed to a mantle plume, melting a metasomatized mantle lithosphere, and lithospheric delamination (Barry et al. 2003; Savatenkov et al. 2010; Hunt et al. 2012; Barry and Kent 2013; Dash et al. 2015). The Hangay volcanic system has been fairly long-lived; dated flows range in age from $\sim 30 \mathrm{Ma}$ to recent ( $\sim \mathrm{Ka}$; Barry and Kent 2013; fig. 2). On the basis of total alkali versus silica contents, the rocks of the Hangay region have a range of classifications including alkali basalt, trachybasalt, basaltic trachyandesite, phonotepherite, tephrite basanite, basaltic andesite, and trachyandesite (Barry et al. 2003). Primitive-mantle-normalized trace-element diagrams for several volcanic localities in the region show enrichment in highly incompatible trace elements and exhibit patterns similar to ocean island basalt (Savatenkov et al. 2010; Barry and Kent 2013). Geochemical modeling suggests that the volcanic rocks must have been derived by low degrees of partial melting of a garnet lherzolite source at depths greater than $70 \mathrm{~km}$ (Tielke 2008). Despite the long-lived nature of the system, there has been no significant change in the major- and trace-element geochemistry and isotope geochemistry of the volcanic rocks, which suggests that the source has remained the same through the duration of volcanism in the region (Ancuta et al. 2013).
While the chemistry of the volcanic rocks has not changed significantly, the surface manifestation of Cenozoic volcanism in the Hangay region has evolved through time. The early phase of volcanism in the Oligocene and Miocene produced thick stacks of plateau-forming basalts that cap paleotopography. Late Miocene through Holocene flows have been referred to as valley fill or lava rivers. These later flows generally exist at lower elevations and in some case are inset into valleys that cut through earlier plateau-forming sequences (Yarmolyuk et al. 2008). Flows of various ages exist at elevations ranging from $\sim 1500$ to $3200 \mathrm{~m}$. Generally, flows in the northern Gobi exist at low elevations and are Oligocene in age, while Miocene though Holocene flows exist at varying elevations throughout the Hangay and into the Hovsgol region (Ancuta et al. 2013). The wide range of ages of flows present at various elevations in the Hangay region makes the area particularly suitable for vesicular-basalt paleoaltimetry.

\section{Field Sampling}

The Hangay Mountains are an extensive region in central Mongolia with rugged topography, few roads, and virtually no infrastructure. Fieldwork relied on previous field studies that located basalt flows as potential targets and on vehicles that were able to travel great distances in the absence of roads of any kind (albeit slowly). In the absence of road cuts, many outcrops had to be examined before a few could be found that were suitable for sampling and subsequent analysis. To be suitable for paleoelevation reconstruction, a lava flow must be completely exposed from (ideally) pahoehoe crust on top to the base, showing an imprint of the pahoehoe surface of the underlying flow. Such well-preserved flows are rarely found in the field even under the best of circumstances, and in the absence of pahoeohoe crust, assessment of the completeness of a flow must normally be made on the basis of the observed vesicularity profile. This is possible because the vesicle size distribution is known as a function of stratigraphic position in the flow for any given thickness of flow (Sahagian et al. 1989). We sampled flows that indicated that even when the pahoehoe crust (typically about $1 \mathrm{~cm}$ thick) was lost, no significant erosion of the upper vesicular zone had occurred, as the chilled top of the flow still preserved a suite of vesicles showing no sign of movement relative to the lava or coalescence due to differential motions. Erosion of the bottoms of lava flows is less of a concern. In the field, it is critical to sample flows whose thickness can be accurately measured. We found suitable lo- 


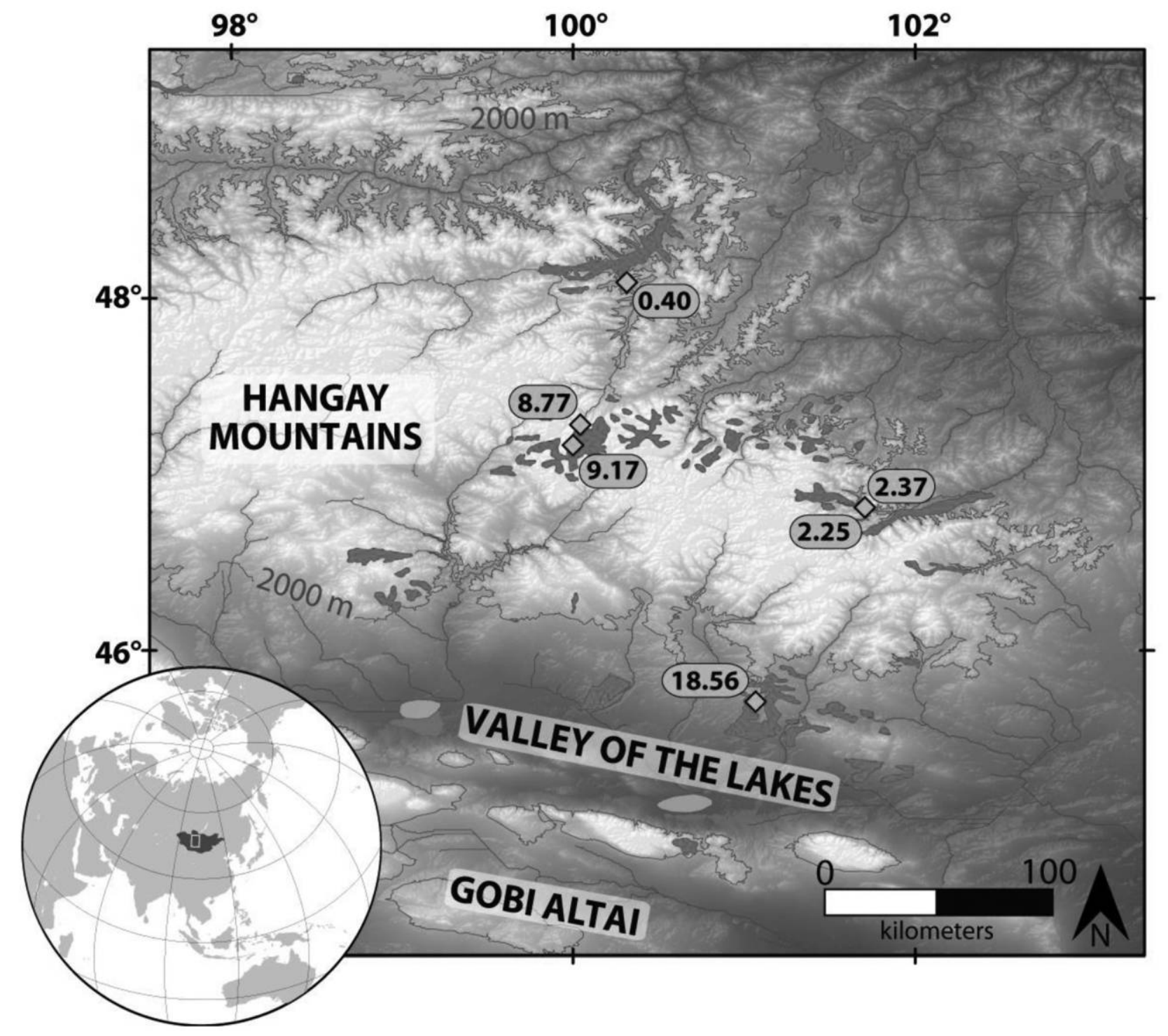

Figure 2. Ages of dated basalts in central Mongolia. The extent of the Hangay Mountains is well outlined by the 2000-m contour line. All ages are reported in millions of years. Many basalt flows were examined, but only those indicated by diamonds satisfied the strict requirements of simple emplacement and preservation and were thus suitable for analysis in this study. A color version of this figure is available online.

cations along cut banks of rivers and streams and along cliff faces (table 1).

The cross section of a suitable flow must show a history of simple emplacement during cooling and solidification of the lava. We avoided flows that contained rip-up clasts, pipe vesicles, and other complications that could confound the analysis. In particular, we were careful to note any signs of potential inflation or deflation of the flow after the top and bottom were solidified. Inflation can be recognized in the field by the presence of extra vesicular zones between the upper and lower vesicular zones expected in a simply emplaced lava (Sahagian 1985;
Sahagian et al. 1989). Deflation can be recognized by an upper vesicular zone that contains large, coalesced vesicles indicative of a relatively thick lava flow $(>3 \mathrm{~m})$ but is observed in the field as a relatively thin flow that either has an inappropriately thin massive zone or lacks one altogether (Sahagian et al. 2002a). Lower vesicular zones are always about $50 \mathrm{~cm}$ thick, underlying a massive, vesicle-free zone. Upper vesicular zones display variability in thickness and vesicle size distribution that depends on the thickness of the flow within which bubbles rise and coalesce. As a lava flow cools, the upper and lower solidification fronts meet at a point $42 \%$ up from the 
Table 1. Sample Locations

\begin{tabular}{lccccc}
\hline Sample ID & \multicolumn{1}{c}{ Age, $\mathrm{Ma}$} & Thickness, $\mathrm{m}$ & Longitude & Latitude & Elevation, $\mathrm{m}$ \\
\hline DS13-6 & $8.77 \pm .14$ & 1.33 & $47^{\circ} 16.144^{\prime} \mathrm{N}$ & $100^{\circ} 01.254^{\prime} \mathrm{E}$ & 2443 \\
DS13-8 & $9.17 \pm .17$ & 2.31 & $47^{\circ} 12.594^{\prime} \mathrm{N}$ & $100^{\circ} 00.630^{\prime} \mathrm{E}$ & 2240 \\
DS13-9 & $9.17 \pm .17$ & 2.26 & $47^{\circ} 12.594^{\prime} \mathrm{N}$ & $100^{\circ} 00.630^{\prime} \mathrm{E}$ & 2242 \\
DS13-11 & $18.56 \pm .27$ & 2.67 & $45^{\circ} 43.006^{\prime} \mathrm{N}$ & $101^{\circ} 04.311^{\prime} \mathrm{E}$ & 1933 \\
DS13-12 & $2.37 \pm .10$ & 3.25 & $46^{\circ} 47.994^{\prime} \mathrm{N}$ & $101^{\circ} 45.643^{\prime} \mathrm{E}$ & 1951 \\
DS13-14 & $2.25 \pm .23$ & 3.30 & $46^{\circ} 47.994^{\prime} \mathrm{N}$ & $101^{\circ} 45.643^{\prime} \mathrm{E}$ & 1951 \\
DS13-17 & $.40 \pm .10$ & 1.80 & $48^{\circ} 05.770^{\prime} \mathrm{N}$ & $100^{\circ} 18.952^{\prime} \mathrm{E}$ & 1833 \\
\hline
\end{tabular}

base of the flow (not halfway), because the top cools by radiation to the atmosphere while the bottom cools by conduction and is insulated by the underlying rock or soil (Sahagian 1985; Sahagian et al. 1989).

Once a flow was examined and determined to satisfy the requirements discussed above, 1 -inchdiameter cores were drilled with a gas-powered coring drill from the top and bottom of the flow (fig. 3). The cores were then examined for any unusual signs of nonuniformity of vesicles or other internal structures that might confound the analysis. Cores were labeled and bagged for x-ray tomographic imaging.

\section{Sample Analysis}

${ }^{40} \mathrm{Ar} /{ }^{39} \mathrm{Ar}$ Geochronology. Samples collected for ${ }^{40} \mathrm{Ar} /{ }^{39} \mathrm{Ar}$ geochronology were processed and dated at the Lehigh University Geochronology Lab. After crushing, washing, and removal of highly magnetic material, a sample consisting of several milligrams of fine-grained polymineralic groundmass was handpicked for irradiation and subsequent dating. The majority of samples were dated by a total-fusion method using $\mathrm{a} \mathrm{CO}_{2}$ laser system coupled to an Argus VI noble-gas mass spectrometer. Select samples were dated via the step heating method. Data were reduced with ArArCALC software (ver. 2.5.2; Koppers 2002). See L. D. Ancuta, P. K. Zeitler, B. D. Idleman, and B. T. Jordan (unpublished manuscript) for a more detailed description of the dating methods.

High-Resolution Computed X-ray Tomography. Computed x-ray tomography scans of 25-mm drilled core samples (table 1) were performed at the University of Texas High-Resolution X-ray CT Facility with a North Star Imaging scanner. Images were acquired by a Perkin Elmer detector, with $0.25-\mathrm{pF}$ gain, in 16-bit grayscale format with the instrument settings in high-power mode: $180 \mathrm{kV}, 0.15 \mathrm{~mA}$. Image resolution, that is, voxel size, for all samples was $31.1 \mu \mathrm{m}$. The number of slices in a scan stack typically ranged from 1500 to 2500 . However, the threedimensional image array of each sample was truncated by a cylindrical region that excluded voxels outside of the sample as well as the tops and bottoms of the sample, where exposed bubble voids are
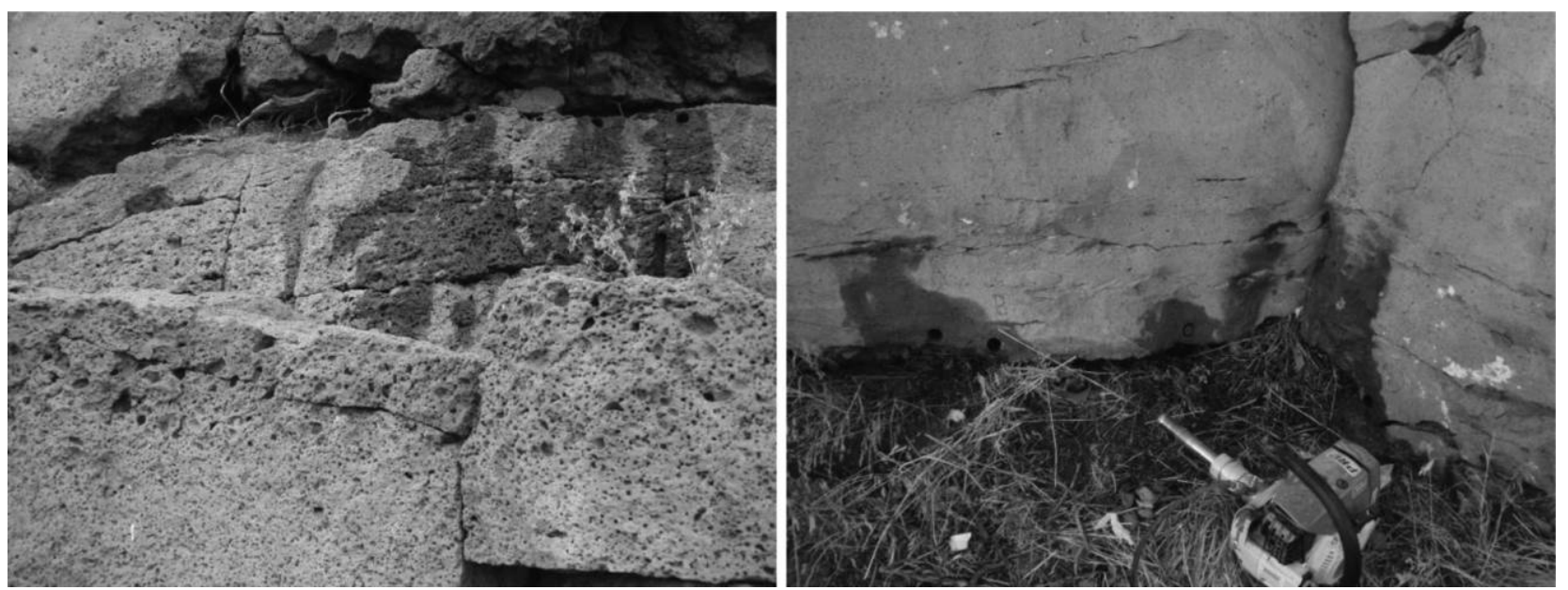

Figure 3. Coring locations at the top (left) and bottom (right) of a typical basaltic lava flow. Cores are $2.5 \mathrm{~cm}(1 \mathrm{inch})$ in diameter. Note that the upper vesicular zone contains many large, coalesced vesicles, while the lower vesicular zone has smaller vesicles and no coalescence. A massive zone separates the two vesicular zones. The darkened areas are wet from the drill-cooling water. A color version of this figure is available online. 
often contaminated with soil, sawdust, or paleosol carbonates. Each pair of image stacks from the top and bottom of each basaltic flow was then visually inspected for consistency in general void and crystal texture, including object sizes, tensile or shear deformation, density, and volume fraction (fig. 4). Top/ bottom pairs with considerable visual inconsistencies were eliminated and thus not included in analysis of paleoelevation (table 2). Segmentation techniques enabled us to distinguish pixels within bubbles from those in groundmass, and characterization of individual vesicles was accomplished through software specially designed for this purpose. The details of these techniques can be found in the appendix, available online, and in previous publications (Proussevitch and Sahagian 2001; Sahagian et al. 2002a; Sahagian and Proussevitch 2007).

\section{Paleoaltimetry Reconstructions}

In this study, paleoaltimetry reconstructions were accomplished on the basis of a statistical analysis of bubble size distributions for sample pairs from tops and bottoms of basaltic lava flows. According to the basic principles of vesicular-basalt paleoaltimetry (Sahagian and Maus 1994; Sahagian et al. $2002 a)$, values of modal bubble volumes at lava flow top/bottom quench zones, combined with measurement of flow thickness, are sufficient to calculate

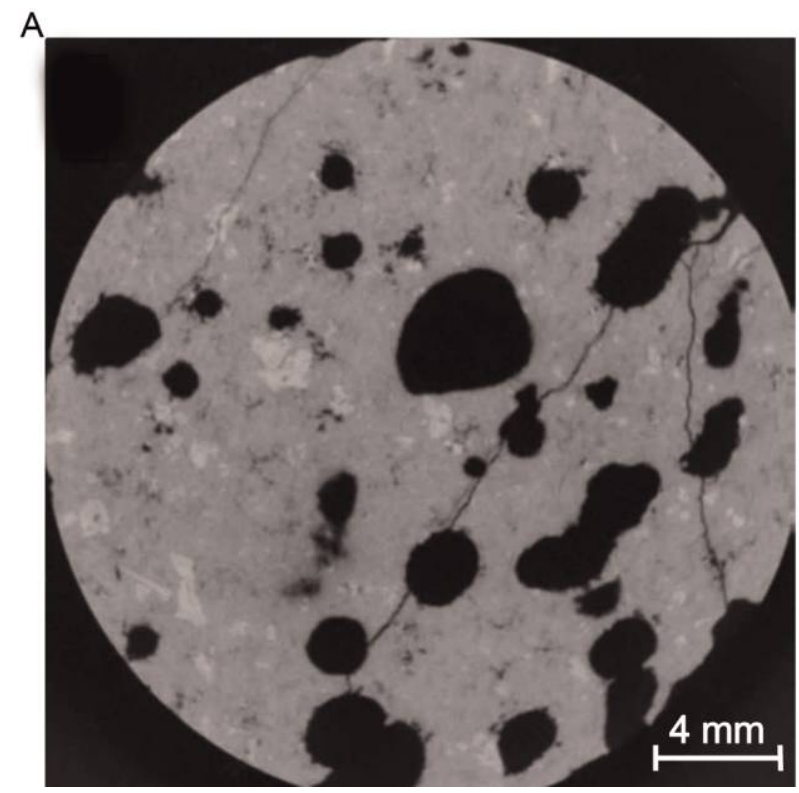

paleoatmospheric pressure at the time of flow emplacement, which, in turn, can be converted to elevation through the "standard" atmosphere pressure profile. A complete example of such reconstruction for one of the studied Mongolian basaltic flows is illustrated in figure 5. It is important to note that bimodal vesicle distributions in vesicular volcanic products including lava flows and pyroclasts are very common (Proussevitch et al. 2007; Colucci et al. 2013; Genareau et al. 2013), which we interpret as representing pre- and syneruptive bubble populations (syneruptive bubbles are commonly an order of magnitude smaller than preeruptive bubbles in diameter), but only preeruptive bubbles are typically suitable for the paleoaltimetry (see table 2). This is in part because preeruptive bubbles are larger and thus more accurately measured and in part because they are less subject to the vagaries of rapid pressure variations and nucleation conditions during eruption. The latter case of syneruptive bubbles may thus violate the vesicular-basalt paleoaltimetry requirement of uniformity in bubble population parameters - specifically, the gas mass inside modal bubbles before these were relegated to the top or bottom of a lava flow.

\section{Results and Discussion}

The paleoelevations determined on the basis of vesicular basalts sampled from the Hangay Moun-

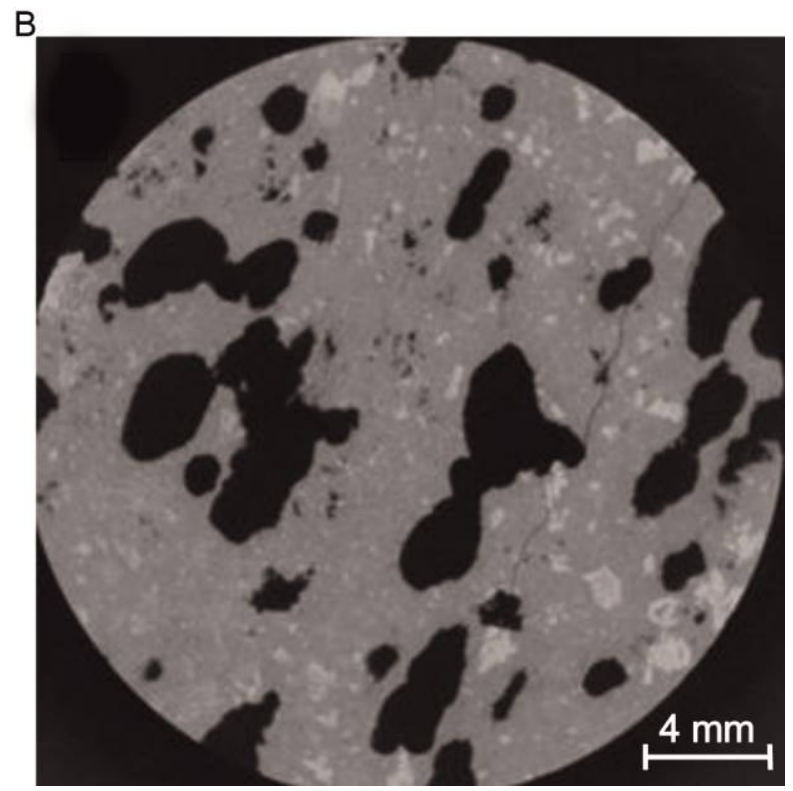

Figure 4. Example of high-resolution x-ray tomographic images of cores taken from the bottom $(A)$ and top $(B)$ of a basaltic lava flow (samples DS13-6B/T [bottom/top]). Voxel resolution is $31 \mu \mathrm{m}$, and the typical number of images in a z-stack is 1500 . 
Table 2. Results of Bubble Size Distribution Statistical Analysis for Mongolia Lava Flow Samples Listed in Table 1

\begin{tabular}{|c|c|c|c|c|c|c|c|c|}
\hline Sample ID & Voxel array & $\begin{array}{l}\text { Segmentation } \\
\text { range }\end{array}$ & $\begin{array}{l}\text { Bubbles } \\
\text { identified }\end{array}$ & Mode, SE & Mode, PE & $\begin{array}{l}\text { Calculated } \\
\text { atm. press. } \\
\text { (atm) }\end{array}$ & $\begin{array}{l}\text { Calculated } \\
\text { elevation }(\mathrm{m})\end{array}$ & Note \\
\hline DS13-6 & & & & & & .895 & 1154 & PE modes \\
\hline Top & $780^{2} \times 810$ & $8-26$ & 3550 & 1.601 & 3.903 & & & \\
\hline Bottom & $780^{2} \times 896$ & $10-30$ & 3313 & 1.451 & 3.759 & & & \\
\hline DS13-6 & & & & & & .853 & 1616 & SE modes \\
\hline Top & $780^{2} \times 810$ & $8-26$ & 3550 & 1.601 & 3.903 & & & \\
\hline Bottom & $780^{2} \times 896$ & $10-30$ & 3313 & 1.451 & 3.759 & & & \\
\hline DS13-8 & & & & & & .900 & 1095 & PE modes \\
\hline Top & $750^{2} \times 1600$ & $8-28$ & 9069 & .885 & 4.200 & & & \\
\hline Bottom & $720^{2} \times 750$ & $8-26$ & 2416 & 1.358 & 3.975 & & & \\
\hline DS13-9 & & & & & & .891 & 1198 & PE modes \\
\hline Top & $760^{2} \times 1700$ & $8-26$ & 23,909 & 1.015 & 3.876 & & & \\
\hline Bottom & $760^{2} \times 1800$ & $8-26$ & 11,542 & 1.590 & 3.653 & & & \\
\hline DS13-11 & & & & & & .857 & 1568 & PE modes \\
\hline Top & $780^{2} \times 1740$ & $8-28$ & 13,927 & 1.473 & 3.282 & & & \\
\hline Bottom & $780^{2} \times 1340$ & 10-30 & 5818 & 1.309 & 3.090 & & & \\
\hline DS13-12 & & & & & & .884 & 1272 & PE modes \\
\hline Top & $750^{2} \times 1900$ & $2-40$ & 7338 & 1.597 & 3.585 & & & \\
\hline Bottom & $780^{2} \times 1900$ & $2-40$ & 3934 & 1.588 & 3.290 & & & \\
\hline DS13-14 & & & & & & .844 & 1712 & $\begin{array}{l}\text { Bulk void } \\
\text { volume }\end{array}$ \\
\hline Top & $780^{2} \times 1900$ & $8-24$ & 18,948 & $\cdots$ & $\cdots$ & & & \\
\hline Bottom & $780^{2} \times 1800$ & $10-28$ & 35,633 & $\ldots$ & $\ldots$ & & & \\
\hline DS13-17 & & & & & & .799 & 2208 & PE modes \\
\hline Top & $780^{2} \times 1300$ & $8-28$ & 14,633 & 1.532 & 3.580 & & & \\
\hline Bottom & $780^{2} \times 1600$ & $8-28$ & 9596 & 1.625 & 3.377 & & & \\
\hline
\end{tabular}

Note. Note that pre-eruptive (PE) mode is used whenever possible, as it involves relatively large vesicles that are accurately resolvable in the X-ray scans. In one case, the PE mode is so shallow and the SE mode is at such a small size, near the minimum spatial resolution of the x-ray technique, that bulk vesicularity must be used, despite the vagaries of presence or absence of rare, very large vesicles that alter the bulk void fraction in the sample. For details regarding interpretation of $\mathrm{x}$-ray tomographic data, see Proussevitch and Sahagian (2001). Mode $=\log _{10}$ modal volume of bubbles; $\mathrm{PE}=$ pre-eruptive bubble population; $\mathrm{SE}=$ syneruptive bubble population; atm. press. $=$ atmospheric pressure.

tains span a range from 1 to $2 \mathrm{~km}$ (table 3). Comparison with present elevations indicate uplift of about $1 \mathrm{~km}$ in the past $9 \mathrm{~m}$.yr. The current data set cannot resolve exactly when this uplift occurred or whether it occurred suddenly, episodically, or smoothly over the 9 m.yr. (fig. 6). On the basis of coeval volcanism in a broader region extending to the north and northeast, it is possible that uplift of central Mongolia represents part of a broader uplifted area being driven by the same mechanism or set of mechanisms and, in turn, affecting the evolution of late Cenozoic climate in Asia as a northern counterpart of the Tibetan Plateau.

The observation that the "summits" throughout the mountains remain morphologically flat and have relatively uniform elevations suggests that uplift may have occurred as a unit over a broad region or over a more limited region bounded by faults that isolated Hangay from the surrounding regions (Jolivet et al. 2007). A single older sample collected from the low-lying region immediately to the south of the Hangay Mountains (southeastern extension of the Valley of Lakes) yielded a paleoelevation result that is indistinguishable from present elevation, given the error bounds of the analysis. This suggests that if Hangay behaved epeirogenically as a unit, the Valley of Lakes and the northern Gobi region, south of a bounding fault, were not involved in the same history. While it is possible that this broader region rose along with the Hangay to the north and then fell to nearly the same elevation from which it started, this cannot be determined on the basis of the one sample (age) obtained. An analysis of precipitation trends based on carbon isotopes in paleosol carbonates (Caves et al. 2014), however, suggests that the Gobi Altai to the south did not experience surface uplift until the Late Miocene, while the Hangay uplift may have begun in the Early Oligocene. Therefore, a broadly regional unified epeirogenic history involving the region to the south of Hangay appears unlikely. However, we cannot rule out a common epeirogenic 


\section{Statistical Analysis for Sample \# DS13-6}

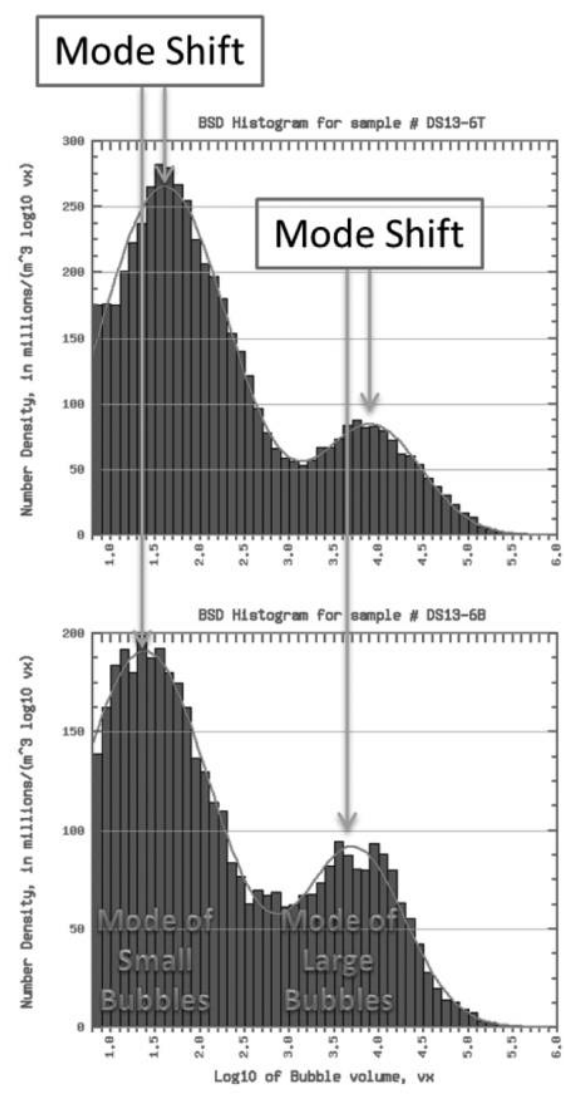

Estimated Paleoelevation by two bubble modes-

- $1616 \mathrm{~m}$ - Mode of small bubbles (syn-eruptive)

- $1154 \mathrm{~m}$ - Mode of large bubbles (pre-eruptive)

Top

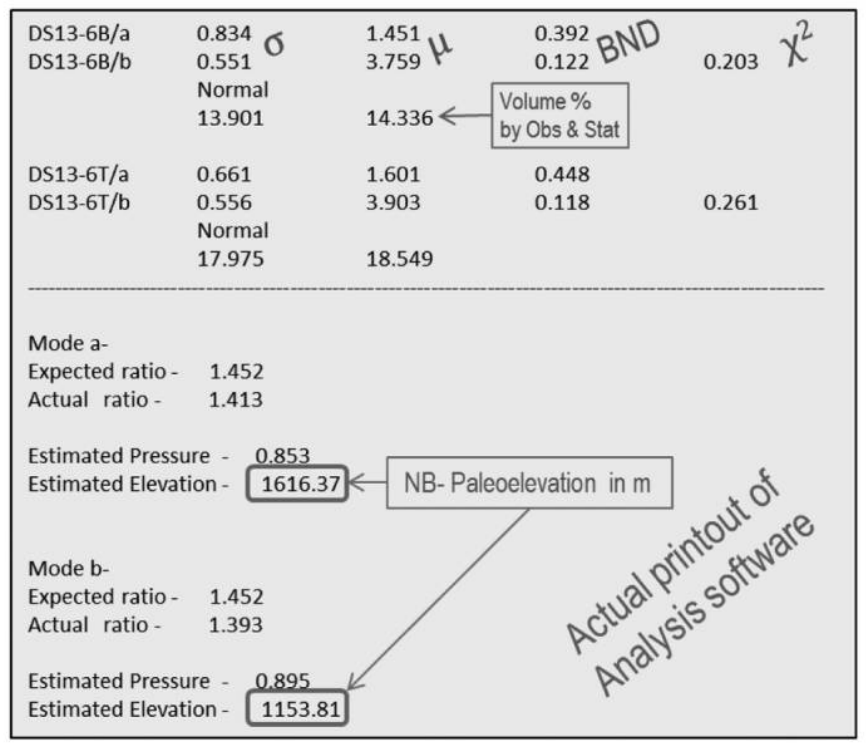

Mode for Large Bubbles is about $1.0 \mathrm{~mm}$ (Diameter)

Bottom Mode for Small Bubbles is about $0.1 \mathrm{~mm}$

Figure 5. Example of statistical analysis of bubble size distribution (BSD) to infer paleoatmospheric pressure at the time of lava flow emplacement. The BSD indicates two bubble size modes that can be interpreted as pre-eruptive (larger bubbles) and syneruptive (smaller). In this case, syneruptive bubbles are about one-tenth the diameter of preeruptive bubbles. Both bubble size modes are shifted toward smaller sizes for the sample from the bottom of the lava flow because of additional compression by lava flow weight (hydrostatic, or "lavastatic," pressure of basaltic melt). The difference in modal bubble sizes between the top (DS13-6T) and bottom (DS13-6B) of lava flow is used to calculate paleoatmospheric pressure, which, in turn, can be converted to elevation with a "standard" atmosphere hypsometric pressure profile. $\sigma=$ standard deviation; $\mu=$ mode; BND = bubble number distribution. A color version of this figure is available online.

Table 3. Results of Paleoelevation Analysis

\begin{tabular}{lcccc}
\hline Sample ID & Age $(\mathrm{Ma})$ & Present elevation $(\mathrm{m})$ & Calculated elevation $(\mathrm{m})$ & Uplift $(\mathrm{m})$ \\
\hline DS13-6 & 8.77 & 2443 & $1616^{\mathrm{a}}$ & $827^{\mathrm{a}}$ \\
DS13-6 & 8.77 & 2443 & $1154^{\mathrm{b}}$ & $1289^{\mathrm{b}}$ \\
DS13-8 & 9.17 & 2240 & 1095 & 1145 \\
DS13-9 & 9.17 & 2240 & 1198 & 1042 \\
DS13-12 & 2.37 & 1951 & 1272 & 679 \\
DS13-14 & 2.25 & 1951 & 1712 & 239 \\
DS13-17 & .40 & 1833 & 2207 & -374 \\
DS13-11 & 18.56 & 1933 & 1568 & 365 \\
\hline
\end{tabular}

Note. Ages were determined by ${ }^{40} \mathrm{Ar} /{ }^{39} \mathrm{Ar}$ dating, current elevations were determined on the basis of existing maps and in situ field GPS, and calculated elevation is the paleoelevation at the time of emplacement on the basis of our analysis. The difference between paleoelevation and current elevation is the uplift since the rock was emplaced.

${ }^{a}$ Using syneruptive modes.

${ }^{\mathrm{b}}$ Using preeruptive modes. 


\section{Hangay Uplift History Recorded in Vesicular Basalts}

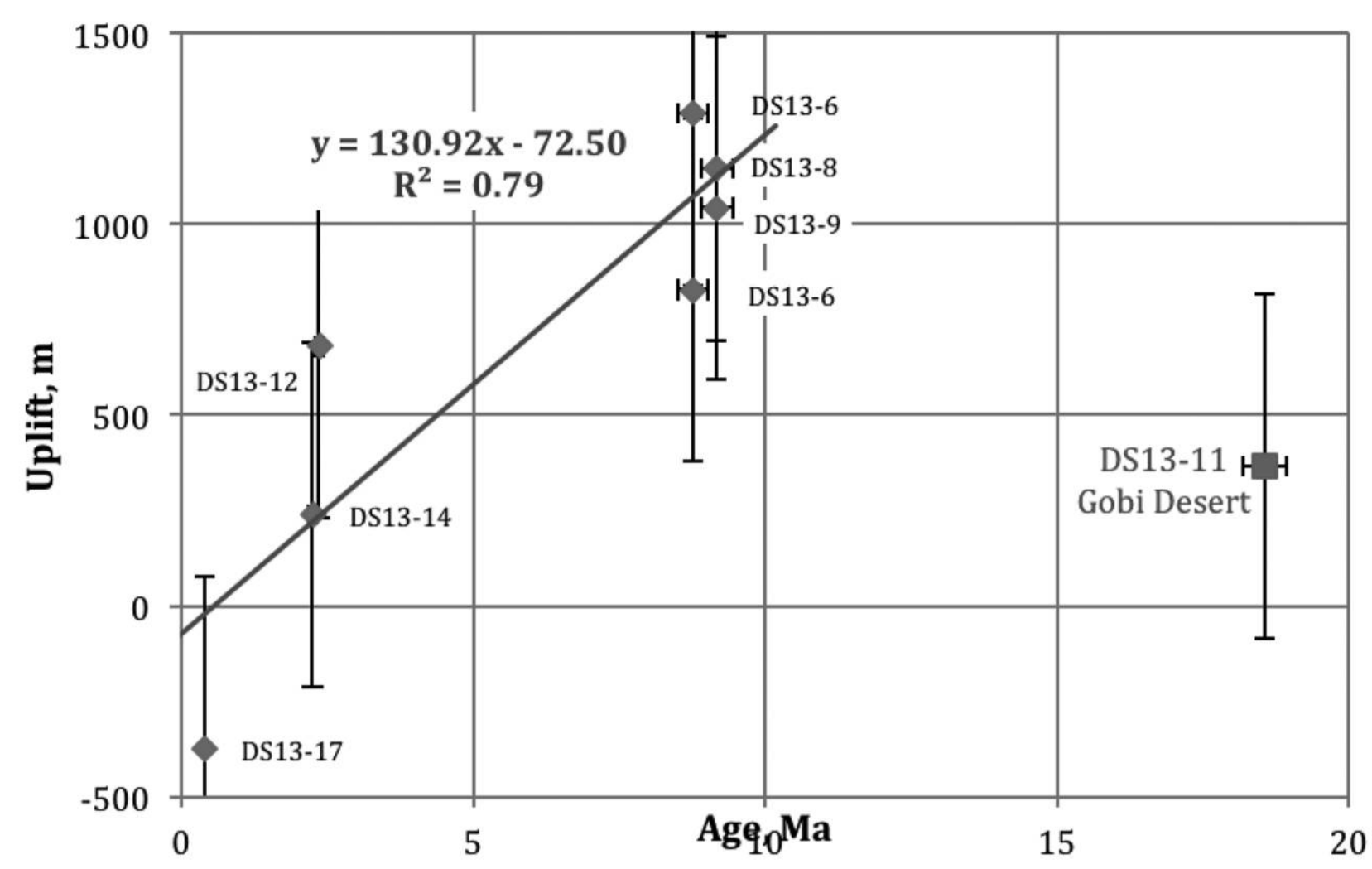

Figure 6. Uplift history of the Hangay Mountains on the basis of paleoelevation determined from vesicular basalts. The relatively small number of data points does not allow us to distinguish between episodic, sudden, and gradual uplift, so a simple best-fit straight line is drawn. The best-fit line was not shifted to pass through $(0,0)$, although this must be its origin. Rather, it is drawn strictly on the basis of the data, and its intersection near the origin is an indication of the veracity of the results of the analysis. A linear regression suggests an average uplift rate of $131 \pm 73 \mathrm{~m} /$ m.yr., with a $95 \%$ confidence interval. The single sample from a southeastern extension of the Valley of Lakes (northern Gobi) suggests that the region immediately south of Hangay underwent a different uplift history. A color version of this figure is available online.

history between Hangay and the broad region to the north and northeast.

The results from vesicular basalts provide an initial constraint regarding the epeirogenic history of this part of central Asia. The rate and amount of uplift over the past 9 m.yr. are not exceptional in any respect, and the data analyzed in this study cannot speak to the history before $9 \mathrm{Ma}$. Thus, it is possible that uplift commenced before that time (Caves et al. 2014) and that the total uplift has been far greater than the $1 \mathrm{~km}$ obtained over the past 9 m.yr. It is also impossible to resolve small variations in the rate of uplift over the past 9 m.yr. The $1 \mathrm{~km}$ of uplift over $9 \mathrm{~m}$.yr. provides, however, an initial constraint on drivers of uplift, suggesting that mechanisms that allow for uplift of about $1 \mathrm{~km}$ in no more than 9 m.yr. are more likely to be operating than those that may require more time (evolve more slowly) than the uplift observed. As additional proxies are explored in the context of our broader project and others, further insights may emerge to shed light on the longer-term history and, consequently, on the driving mechanism(s) of the Hangay uplift.

\section{A C KN O W LEDG MENTS}

This project was supported by National Science Foundation grant EAR-1009680. 


\section{REFEREN C E S C I T E D}

Ancuta, L. D.; Carlson, R. W.; Idleman, B. D.; and Zeitler, P. K. 2013. Geochemistry and geochronology of Hangay Dome volcanic rocks: exploring the source of high topography and volcanism in an intracontinental setting. American Geophysical Union Fall Meeting, abstract T42B-08.

Bao, X.; Eaton, D. W.; and Guest, B. 2014. Plateau uplift in western Canada caused by lithospheric delamination along a craton edge. Nat. Geosci. 7:830-833.

Barry, T. L., and Kent, R. W. 2013. Cenozoic magmatism in Mongolia and the origin of Central and East Asian basalts. In Flower, M. F. J.; Chung, S.-L.; Lo, C.-H.; and Lee, T.-Y., eds. Mantle dynamics and plate interactions in East Asia. Washington, DC, American Geophysical Union, p. 347-364.

Barry, T. L.; Saunders, A. D.; Kempton, P. D.; Windley, B. F.; Pringle, M. S.; Dorjnamjaa, D.; and Saandar, S. 2003. Petrogenesis of Cenozoic basalts from Mongolia: evidence for the role of asthenospheric versus metasomatized lithospheric mantle sources. I. Petrol. 44:55-91.

Burov, E., and Gerya, T. 2014. Asymmetric threedimensional topography over mantle plumes. $\mathrm{Na}-$ ture 513:85-89. doi:10.1086/nature13703.

Calixto, F. J.; Sandvol, E. A.; Kay, S. M.; Mulcahy, P.; Heit, B.; Yuan, X.; Coira, B.; Comte, D.; and Alvarado, P. M. 2013. Velocity structure beneath the southern Puna Plateau: evidence for delamination. Geochem. Geophys. Geosyst. 14:4292-4305.

Caves, J. K.; Sjostrom, D. J.; Mix, H. T.; Winnick, M. J.; and Chamberlain C. P. 2014. Aridification of Central Asia and uplift of the Altai and Hangay Mountains, Mongolia: stable isotope evidence. Am. I. Sci. 314:11711201.

Colucci, S.; Palladino, D. M.; Mulukutla, G. K.; and Proussevitch, A. A. 2013. 3-D reconstruction of ash vesicularity: insights into the origin of ash-rich explosive eruptions. J. Volcanol. Geotherm. Res. 255: 98-107.

Dash, B.; Yin, A.; Jiang, N.; Tseveendorj, B.; and Han, B. 2015. Petrology, structural setting, timing, and geochemistry of Cretaceous volcanic rocks in eastern Mongolia: constraints on their tectonic origin. Gondwana Res. 27:281-299.

de Ignacio, C.; López, I; Oyarzun, R; and Márquez, A. 2001. The northern Patagonia Somuncura Plateau basalts: a product of slab-induced, shallow asthenospheric upwelling? Terra Nova 13:117-121.

Geist, D., and Richards, M. 1993. Origin of the Columbia Plateau and Snake River plain: Deflection of the Yellowstone plume. Geology 21:789-792.

Genareau, K.; Mulukutla, G.; Proussevitch, A.; Durant, A.; Rose, W.; and Sahagian, D. 2013. The size range of bubbles that produce ash during explosive volcanic eruptions. J. Appl. Volcanol. 2:4. doi:10.1186/21915040-2-4.

Hunt, A. C.; Parkinson, I. J.; Harris, N. B. W.; Barry, T. L.; Rogers, N. W.; and Yondon, M. 2012. Ce- nozoic volcanism on the Hangai Dome, central Mongolia: geochemical evidence for changing melt sources and implications for mechanisms of melting. I. Petrol. 53:1913-1942.

Jolivet, M.; Ritz, J.-F.; Vassallo, R.; Larroque, C.; Braucher, R.; Todbileg, M.; Chauvet, A.; et al. 2007. Mongolian summits: an uplifted, flat, old but still preserved erosion surface. Geology 35:871-874.

Koppers, A. A. P. 2002. ArArCALC-software for ${ }^{40} \mathrm{Ar} /$ ${ }^{39} \mathrm{Ar}$ age calculations. Comput. Geosci. 28:605-619.

Lu, R.; He, D.; Xu, X.; and Liu, B. 2016. Crustal-scale tectonic wedging in the central Longmen Shan: constraints on the uplift mechanism in the southeastern margin of the Tibetan Plateau. I. Asian Earth Sci. 117: 73-81.

Parfeevets, A., and Sankov, V. 2012. Late Cenozoic tectonic stress field on the Mongolian microplate. C. R. Geosci. 344:227-238.

Powell, C. M. 1986. Continental underplating model for the rise of the Tibetan Plateau. Earth Planet. Sci. Lett. 81:79-94.

Proussevitch, A. A., and Sahagian, D. L. 2001. Recognition and separation of discrete objects within complex 3D voxelized structures. Comput. Geosci. 27: 441-454.

Proussevitch, A. A.; Sahagian, D. L.; and Carlson, W. D. 2007. Statistical analysis of bubble and crystal size distributions: application to Colorado Plateau basalts. J. Volcanol. Geotherm. Res. 164:112-126.

Sahagian, D. L. 1985. Bubble migration and coalescence during the solidification of basaltic lava flows. I. Geol. 93:205-211.

2005. Paleoelevation measurement: combining proxies and approaches. EOS: Trans. Am. Geophys. Union 86(48):500. doi:10.1029/2005EO480007.

Sahagian, D. L., and Maus, J. E. 1994. Basalt vesicularity as a measure of atmospheric pressure and paleoelevation. Nature 372:449-451.

Sahagian, D. L., and Proussevitch, A. A. 2007. Paleoelevation measurement on the basis of vesicular basalts. Rev. Mineral. Geochem. 66:195-213.

Sahagian, D. L.; Anderson, A. T.; and Ward, B. 1989. Bubble coalescence in basalt flows: comparison of a numerical model with natural examples. J. Volcanol. Geotherm. Res. 52:49-56.

Sahagian, D. L.; Proussevitch, A. A.; and Carlson, W. D. 2002a. Analysis of vesicular basalts and lava emplacement processes for application as a paleobarometer/paleoaltimeter. I. Geol. 110:671-685.

. 2002b. Timing of Colorado Plateau uplift: initial constraints from vesicular basalt-derived paleoelevations. Geology 30:807-810.

Savatenkov, V. M.; Yarmolyuk, V. V.; Kudryashova, E. A.; and Kozlovskii, A. M. 2010. Sources and geodynamics of the Late Cenozoic volcanism of central Mongolia: evidence from isotope-geochemical studies. Petrology 18:278-307. 
Tielke, J. A. 2008. Stratigraphy of Miocene lavas of the Hangay Mountains, Mongolia: implications for magmatic origin, evolution, and orogeny. BS honors thesis. University of South Dakota, Vermilion.

Wendlandt, E.; DePaolo, D. J.; and Baldridge, W. S. 1993. Nd and Sr isotope chronostratigraphy of Colorado Plateau lithosphere: implications for magmatic and tectonic underplating of the continental crust. Earth Planet. Sci. Lett. 116:23-43.
Yarmolyuk, V. V.; Kudryashova, E. A.; Kozlovsky, A. M.; and Lebedev, V. A. 2008. Late Cenozoic volcanism of Khangai (central Mongolia): evidence for recent orogeny in Central Asia. Dokl. Earth Sci. 422:1032-1036.

Yarmolyuk, V. V.; Kudryashova, E. A.; Kozlovskyi, A. M.; and Savatenkov, V. M. 2011. Late Cenozoic volcanic province in Central and East Asia. Petrology 19:327-347.

Zindler, A., and Hart, S. 1986. Chemical geodynamics. Annu. Rev. Earth Planet. Sci. 14:493-571. 